\title{
NA ŚCIEŻCE KARIERY: TŁUMACZ TEKSTÓW MEDYCZNYCH W KONTEKŚCIE WYMAGAŃ ZAWODOWYCH
}

DOl: http://dx.doi.org/10.12775/RP.2017.011

\begin{abstract}
Zarys treści: Tłumaczenie tekstów medycznych obejmuje cały szereg różnego rodzaju dokumentów (np. dokumentację urzędową związaną z obrotem produktami leczniczymi i wyrobami medycznymi, teksty medyczne o charakterze edukacyjno-informacyjnym czy też dokumentację medyczną dotyczącą stanu zdrowia pacjenta). Wyzwaniem dla tłumacza jest więc specjalistyczna terminologia oraz konieczność posiadania i ciągłego pogłębiania wiedzy związanej z dziedziną. W artykule zostaną przedstawione wyzwania i wymagania, którym musi sprostać tłumacz tekstów medycznych.
\end{abstract}

Słowa kluczowe: tłumaczenie tekstów medycznych, język specjalistyczny, tekst medyczny, terminologia, kompetencja.

\section{Czym jest tekst medyczny?}

Teksty medyczne należą do kategorii tekstów specjalistycznych: ich celem jest przekazanie obiektywnej (czy nawet zobiektywizowanej) informacji jak twierdzi Vicent Montalt-Resurrecció (2007), celem takiego tekstu nie jest natomiast przekaz odniesień kulturowych. Wynikiem takich zabiegów jest względnie neutralny, bezosobowy i jednorodny styl.

Teksty medyczne można wstępnie podzielić na trzy podstawowe grupy:

a) dokumentacja urzędowa - to wszelkie dokumenty wymagane przez urzędy do zatwierdzenia do obrotu produktami leczniczymi i wyrobami medycznymi (tzw. regulatory documents); są to dokumenty 
zazwyczaj bardzo obszerne z racji konieczności spełnienia wymagań formalnych i merytorycznych, należą do nich np. protokoły i sprawozdania z badań klinicznych, formularze świadomej zgody pacjenta, dokumenty podsumowujące, jak Wspólny Dokument Techniczny CTD (ang. Common Technical Document) czy też streszczenie i analiza danych zbieranych przez firmę $w$ trakcie opracowywania produktów medycznych;

b) teksty edukacyjno-informacyjne - ten typ tekstów trafia do ściśle określonych grup odbiorców docelowych (mogą to być lekarze lub pacjenci); do takich tekstów zaliczamy np. informacje na temat nowo wprowadzanych leków, prezentacje wyników badań na konferencjach medycznych, artykuły do czasopism medycznych czy też materiały do kształcenia kadr medycznych, w tym kształcenia podyplomowego;

c) dokumentacja medyczna dotycząca stanu zdrowia pacjenta - są to np. wypisy szpitalne, epikryzy, wyniki badań diagnostycznych czy opisy badań.

Wszystkie wymienione powyżej przykłady typów tekstów mogą stać się przedmiotem aktywności tłumacza, który musi zwrócić uwagę na różne wymagania i cechy związane z poszczególnymi rodzajami tekstu. Do takich cech możemy zaliczyć składnię, terminologiczność, złożoność i precyzję, a zatem są to cechy typowe dla języka specjalistycznego. Nieobecność odniesień kulturowych - wspomniana typowa cecha tekstów medycznych - dla tłumacza oznacza konieczność położenia większego nacisku na funkcję informatywną tekstu.

Teksty medyczne to obecnie niezwykle prężnie rozwijająca się dziedzina wymagająca tłumaczenia tysięcy stron (choćby $\mathrm{z}$ racji przynależności Polski do Unii Europejskiej i wiążących się z tym wymagań, dotyczących np. wprowadzania wyrobów medycznych do obrotu, wynikających $\mathrm{z}$ implementacji prawa unijnego do polskiego, nie wspominając o leczeniu w obrębie UE czy uczestniczeniu w życiu naukowym czy badaniach międzynarodowych). Oczywisty więc jest fakt, że takie teksty muszą być przetłumaczone $\mathrm{w}$ sposób adekwatny, terminologicznie spójny oraz odpowiadający potrzebom i oczekiwaniom odbiorcy. Przed tłumaczem zatem pojawiają się wyzwania, wymagania i oczekiwania, którym musi sprostać. 


\section{Tłumacz tekstów medycznych: wyzwania i wymagania}

Kwestie dotyczące terminologii, zastosowania języka łacińskiego czy też wszechobecnych skrótów i skrótowców zostały omówione w innym artykule (Kościałkowska-Okońska 2015), natomiast poniżej odniesiemy się do innych niezwykle ważnych kwestii dotyczących kompetencji, które musi posiadać tłumacz. Nie będziemy się zajmować omawianiem kolejnych wieloskładnikowych definicji i modeli kompetencji, ponieważ na ten temat napisano już wiele (np. Risku 1998; Beeby 2000; Schäffner i Adab 2000); ponadto te kwestie nie są celem niniejszego artykułu. Skupimy się natomiast na komponentach kompetencji w praktycznym wymiarze odnoszących się stricte do kontekstu przekładu tekstów medycznych. Co prawda Marla O’Neill (1998) twierdzi, że aby być tłumaczem tekstów medycznych, najlepiej być lekarzem, natomiast nie każdy z tłumaczy tekstów medycznych (włączając w to grono również autorkę tekstu) ma przywilej posiadania takiego wykształcenia.

Komponenty kompetencji, które przydatne są w tłumaczeniu tekstów medycznych, można sprowadzić do kilku punktów.

1. Język - znajomość języka specjalistycznego (terminologii medycznej) jest warunkiem sine qua non adekwatnego przekładu. Dotyczy to formy i funkcji terminów medycznych w obu językach, znajomości chemicznych, generycznych i handlowych nazw leków (przy tłumaczeniu ulotek lekowych np. nazwą chemiczną substancji aktywnej jest paracetamol, a nazwą handlową leki produkowane zawierające tę substancję, np. APAP, Panadol, Paracetamol, Codipar czy Efferalgan). Terminologia powinna być ponadto ustandaryzowana ze względu na obowiązujące mianownictwo terminologiczne i istniejące klasyfikacje (np. Międzynarodową Klasyfikację Chorób/International Classification of Diseases [ICD]).

Istotna jest również świadomość i znajomość istnienia wariantów językowych w obrębie tego samego języka (brytyjska i amerykańska odmiana angielskiego). Wspomniane różnice w wariantach językowych mogą stanowić problem np. przy odszyfrowywaniu skrótowców: obrzęk kończyny dolnej to w brytyjskim angielskim LEO (Lower Extremity Oedema), natomiast w amerykańskim angielskim ten skrótowiec to LEE (Lower Extremity Edema). Podobnie sytuacja przedstawia się np. w przypadku hormonalnej (estrogenowej) terapii zastępczej - w brytyjskim angielskim to Oestrogen-Replacement Therapy (stąd skrótowiec ORT), a w amerykańskim angielskim mamy Estrogen-Replacement Therapy (ERT). 
2. Komunikacja i kwestie kulturowe dotyczą świadomości istnienia różnych odbiorców docelowych, ich motywacji, oczekiwań i celów. Przydatna jest również znajomość zasad funkcjonowania systemu opieki zdrowotnej, aby umieć dotrzeć do potrzebnych źródeł informacji niezbędnych w danej sytuacji tłumaczeniowej. Tekst tworzony przez tłumacza powinien mieć odpowiedni rejestr przeznaczony dla konkretnej grupy użytkowników (np. jeżeli chodzi o informacje o leku dla lekarzy i dla pacjentów), co widać bardzo dobrze na przykładzie ulotki lekowej dla pacjenta. Ulotka musi być zgodna z Charakterystyką Produktu Leczniczego (ChPL), która jest dokumentem obowiązującym dla wszystkich dopuszczonych do obrotu produktów leczniczych i wyrobów medycznych. Zarówno ulotka, jak i ChPL są dokumentami informacyjnymi i zatwierdza je Urząd Rejestracji Produktów Leczniczych, Wyrobów Medycznych i Produktów Biobójczych. ChPL zawiera takie informacje, jak: wskazania do stosowania leku, jego dawkowanie, działania niepożądane, interakcje, przeciwwskazania, ostrzeżenia i środki ostrożności, a także właściwości farmakologiczne, farmakokinetyczne i toksykologiczne. Oczywiste jest więc, że zarówno informacje tam zawarte, jak i sposób ich przedstawienia przeznaczone są dla osób wykonujących zawód medyczny (lekarz, farmaceuta, stomatolog); ponadto ChPL jest obszerna (zazwyczaj liczy kilkanaście stron), zawiera fachową terminologię medyczną, której przeciętny użytkownik (pacjent) może nie zrozumieć. Drukiem informacyjnym dla pacjenta jest natomiast ulotka informacyjna zawierająca informacje dotyczące bezpieczeństwa stosowania produktu leczniczego i sposób jego użycia.

3. Znajomość pojęć medycznych jest absolutnie niezbędna. Oczywiście wiedza terminologiczna rozwija się i jest poszerzana w ciągu pracy zawodowej wraz z nabywaniem profesjonalnego doświadczenia przez tłumacza. Budowanie leksykonu słownictwa medycznego dobrze jest zatem zacząć od znajomości głównych pojęć z takich dziedzin, jak: anatomia, fizjologia, histologia, biochemia, zdrowie psychiczne czy opieka zdrowotna.

4. Umiejętność tłumaczenia i tworzenia tekstu - w tym punkcie nie skupiamy się na realizacji danego modelu stosowanego w teoriach przekładoznawczych, lecz na kwestiach warsztatowych. Przede wszystkim w tłumaczeniu medycznym przekład nie zmienia przekazu informatywnego tekstu wyjściowego - „nasycenie” informacyjne tekstu musi być identyczne, ponieważ informacje zawarte w tekście 
docelowym muszą być zgodne z prawdą i spójne. Doświadczenie tłumacza przejawia się ponadto w znajomości etapów tłumaczenia, strategii oraz procedur tłumaczeniowych potrzebnych do adekwatnego przetłumaczenia tekstu medycznego.

Z racji specyfiki tłumaczenia tekstów medycznych - często są to, jak już wspomniano powyżej, obszerne dokumenty (np. przy badaniach klinicznych czy dokumentacji lekowej przy wprowadzaniu preparatu do obrotu mogą liczyć kilkaset i więcej stron) - ich złożoności oraz konsekwencji związanych ze skutkami nieadekwatnego tłumaczenia (tym zagadnieniom również poświęcimy miejsce w tym artykule) poszczególne etapy tłumaczenia mogą wyglądać nieco odmiennie. Pierwszy etap to analiza potrzeb klienta (oczekiwań użytkowników danego produktu), następnie zrozumienie tekstu wyjściowego, tworzenie glosariusza, sporządzenie pierwszej wersji tłumaczenia, korekta i edycja, konsultacja ze specjalistą oraz końcowa weryfikacja przez klienta (np. jeżeli jest to firma farmaceutyczna lub zespół badawczy).

Analiza potrzeb klienta polega na omówieniu specyfiki projektu z klientem, a następnie na planowaniu danego projektu, co z kolei obejmuje koordynację pracy z innymi tłumaczami (jeżeli istnieje taka potrzeba przy dużych projektach), zarządzanie terminologią oraz kontakt ze specjalistami. Zrozumienie tekstu wyjściowego to podstawowa zasada tłumaczenia w ogóle, a przekładu tekstu specjalistycznego w szczególności. Właściwe przetłumaczenie tekstu zależy od jego zrozumienia nie tylko na poziomie leksyki (terminologii medycznej w tym wypadku), ale również istniejących hierarchii i zależności pomiędzy terminami i pojęciami, zrozumienia wewnętrznej logiki i spójności tekstu oraz związków przyczynowo-skutkowych. Tworzenie glosariusza jest konieczne w celu ujednolicenia terminologii (wewnętrznie $\mathrm{w}$ tekście - oraz zewnętrznie - zgodnie z wymaganiami i preferencjami klienta). Ponadto tworzenie słownika na własny użytek pomaga w przyswojeniu nowych pojęć, ich definicji oraz kontekstowego zastosowania.

Przy sporządzaniu pierwszej wersji tłumaczenia istotne są przede wszystkim struktura i zawartość treściowa tekstu, ponieważ na tym właśnie etapie tłumacz musi rozwiązać ewentualne problemy tłumaczeniowe (natomiast wszelkie kwestie natury formalnej są rozwiązywane na dalszym etapie pracy nad tekstem). Korektę i późniejszą edycję tekstu wykonuje się w celu osiągnięcia kompletności i komplementarności pojęć, dokładności i jasności wywodu, wewnętrznej spójności, poprawności składniowej, stylistycznej, gramatycznej, ortograficznej i interpunkcyjnej, a także konsekwencji w stosowaniu terminów, skrótów, skrótowców, liczb, nazw własnych itp. Innymi słowy wynikiem korekty i edycji tekstu jest zwarty i logiczny ciąg od zawar- 
tości treściowej tekstu do przecinka: tekst końcowy jest tekstem kompletnym i poprawnym pod każdym względem, poczynając od kwestii merytoryczno-terminologicznych, a kończąc na wyglądzie graficznym.

W trakcie konsultacji ze specjalistą uzyskuje się wszelkie uwagi i komentarze merytoryczne przed ostateczną publikacją; w tym czasie dokonywana jest również końcowa weryfikacja przez klienta, a gotowy tekst - zgodnie $\mathrm{z}$ ustaleniami: czy to $\mathrm{w}$ formie umowy ustnej. czy pisemnej - przekazywany jest klientowi.

5. Zasoby informacyjne to możliwość wykorzystania przez tłumacza źródeł, takich jak np. słowniki medyczne (zarówno konwencjonalne jak i dostępne on-line), atlasy, podręczniki, książki i artykuły naukowe czy dostępne bazy danych. Korzystanie z takich źródeł oznacza umiejętność szukania i znajdowania informacji oraz oceny ich jakości, a także weryfikację uzyskanych informacji w ramach współpracy ze specjalistą z danej dziedziny.

6. Praktyka zawodowa to - poza oczywistą realizacją i weryfikacją w praktyce własnej wiedzy i doświadczenia - również sprawdzian własnych kompetencji interpersonalnych wyrażających się w umiejętności negocjacji i komunikacji z klientem (dotyczącej również kwestii terminologicznych), uzyskania informacji od klienta, a także umiejętności pracy w zespole i terminowości. Nie można również pominąć znajomości kwestii prawnych mających znaczenie dla praktyki tłumaczeniowej, świadomości znaczenia wykonywanej pracy i sposobu jej realizacji.

7. Podejście, nastawienie i motywacja do wykonywanego zadania są również niezwykle ważne. Przede wszystkim należy być świadomym relewantności i celowości wykonywanego zadania. Tłumacz powinien zdawać sobie sprawę ze znaczenia ustawicznego pogłębiania własnej wiedzy i motywacji wewnętrznej (jako czynnika stymulującego i zwiększającego kreatywność, zob. Amabile 1996), bez której trudno byłoby utrzymać na stałym, wysokim poziomie chęć ciągłego uczenia się. Tłumacz musi umieć - także w rozmowie z klientem i/ lub ekspertem - uzasadnić swoje decyzje tłumaczeniowe, przedstawić ich podstawy i przyjmować sugestie oraz uwagi (w tym krytyczne). Bardzo istotna jest świadomość własnej tożsamości zawodowej oraz własnych silnych i słabych stron.

Omówione powyżej punkty w wielu miejscach stanowią kwestie natury uniwersalnej i mogą być zastosowane w wielu sytuacjach tłumaczeniowych przy różnych typach tekstów. Czynnikiem powodującym ich inherentność 
w tłumaczeniu tekstów medycznych jest nacisk na znaczenie wiedzy terminologicznej i kontekstowej, którą powinien charakteryzować się tłumacz, jak również aspektów kompetencyjnych $\mathrm{w}$ wielu wymiarach. Warto podkreślić, że brak lub deficyty na płaszczyźnie kompetencyjnej w zakresie wiedzy z racji tematyki tłumaczonych tekstów mogą spowodować bardzo poważne konsekwencje natury medycznej i prawnej. Na przykład błędy tłumaczeniowe pojawiające się $\mathrm{w}$ artykułach naukowych czy wystąpieniach konferencyjnych mogą podważyć reputację autora tekstu. W przypadku ulotek lekowych błąd w tłumaczeniu może być mylący dla lekarza, ale również dla pacjenta (np. dawkowanie, działania niepożądane itp.). Brak tłumaczenia (wynikający z przeoczenia tłumacza lub - co gorsza - ze świadomej „strategii” pomijania terminów problematycznych) czy też nieadekwatne tłumaczenie mogą stać się przyczyną niewłaściwej diagnozy lub nieodpowiedniej metody leczenia.

Co więcej, teksty medyczne posiadają różnych odbiorców, dla potrzeb których tekst należy - jeżeli jest to możliwe - dostosować. Trudno oczywiście dostosować tłumaczenie wypisu szpitalnego do potrzeb przeciętnego pacjenta, ponieważ wypis ten służy jako materiał informacyjny dla ewentualnych dalszych konsultacji lekarskich. I tak na przykład określenie „Obraz CT przemawia za morbus neoplasmaticus disseminata o niejasnym ognisku pierwotnym" może być niezrozumiałe dla przeciętnego pacjenta ze względu na zastosowane pojęcie łacińskie (czyli „rozsianą chorobę nowotworową") czy angielski skrót CT oznaczający tomografię komputerową. Natomiast inaczej już wygląda kwestia tłumaczenia np. materiałów informacyjnych dla pacjentów, których celem jest osiągnięcie skuteczności komunikacyjnej, czyli zrozumienie przez pacjenta zaprezentowanej mu informacji. Można postawić zatem generalne pytanie: kim jest odbiorca tekstu medycznego?

Naszym odbiorcą może być pracownik szeroko pojętego sektora medycznego (lekarz, pielęgniarka, fizjoterapeuta, personel pomocniczy, administracja szpitalna), ale również pacjent (np. o zwiększającym się znaczeniu potrzeb pacjenta odnośnie do udziału w procesie leczenia piszą Vicent Montalt-Resurrecció i Mark Shuttleworth 2012), któremu przetłumaczony tekst może być potrzebny do dokumentacji przy ubieganiu się np. o odszkodowanie tytułem umowy ubezpieczeniowej lub podjęcia leczenia w krajach Unii Europejskiej, czy naukowiec chcący opublikować artykuł w zagranicznym, wysoko punktowanym, prestiżowym piśmie. Odbiorca może też pełnić rolę klienta zlecającego tłumaczenie, który działa w sektorze publicznym bądź prywatnym. Sektor publiczny stanowią instytucje międzynarodowe, agendy rządowe, uniwersytety czy instytuty badawcze. Dotyczy to również usług tłumaczeniowych świadczonych dla szpitali i ochrony zdrowia w postaci 
tłumaczenia środowiskowego (najczęściej ustnego, w krajach z dużą liczbą imigrantów). Sektor prywatny natomiast to laboratoria, kliniki i szpitale, producenci sprzętu medycznego i wyrobów medycznych, firmy działające w sektorze usług medycznych czy osoby prywatne. Tłumacz przed wykonaniem tłumaczenia powinien zastanowić się, jakie są wymagania klienta, jakiego produktu lub usługi klient oczekuje. Istotny może być również profil odbiorcy docelowego czy firmy korzystającej z tekstu lub kontekstu, w jakim ten tekst zostanie wykorzystany. Tłumacz powinien mieć świadomość znaczenia potencjalnych wymogów prawnych, które mogą mieć wpływ na generowanie tekstu docelowego (np. umowa o zachowaniu poufności, którą ma podpisać tłumacz przed przystąpieniem do tłumaczenia może utrudnić z prawnego punktu widzenia konsultowanie tekstu ze specjalistą $\mathrm{z}$ racji zakazu ujawniania wszelkich informacji). Może się zdarzyć, że klient lub firma posiadają preferencje terminologiczne bądź wymagają od tłumaczy stosowania glosariuszy w celu zachowania spójności tłumaczonego tekstu.

Bezwzględnie jednak priorytetem i celem tłumacza jest przekazanie zawartości informacyjnej oryginału, co jest z kolei warunkowane zrozumieniem tekstu wyjściowego w oparciu o wiedzę merytoryczną i kontekst. $\mathrm{W}$ przeciwnym razie tłumacz będzie skazany na popełnianie błędów, których konsekwencje mogą być czasem trudne do wyobrażenia albo mogą znacznie utrudnić lub wydłużyć proces leczenia. Jako przykład takiej sytuacji może posłużyć fragment tłumaczenia wypisu szpitalnego z Wielkiej Brytanii ${ }^{1}$, stanowiącego część dokumentacji medycznej potrzebnej do ubiegania się o zwrot kosztów leczenia. Pelvic and paraortic lymphadectomy (czyli usunięcie węzłów [chłonnych] miednicznych i okołoaortalnych) przetłumaczono jako pelviniczne i paraortne usunięcie węzłów. W takim tłumaczeniu widoczny jest nie tylko brak znajomości terminologii i wiedzy merytorycznej zaprezentowany przez tłumacza, ale również brak chęci i uzupełnienia deficytów wiedzy oraz nieumiejętność korzystania ze źródeł - źródła internetowe, nie mówiąc o konwencjonalnych, bardzo szybko pozwalają na ustalenie właściwego odpowiednika.

Tytułem podsumowania należy więc mocno podkreślić, że wymienione w punkcie 2 komponenty kompetencji tłumacza odgrywają rolę pierwszoplanową. Jak już wspomniano, są one manifestowane nie tylko w wymiarze kompetencji językowej, ale na szerszej - płaszczyźnie przekazywania infor-

\footnotetext{
${ }^{1}$ Tekst tłumaczenia (wykonany przez tłumacza przysięgłego) z uwagi na niedociągnięcia tłumaczeniowe natury merytorycznej trafił do autorki tekstu celem dokonania korekty, aby mógł zostać zaakceptowany przez polską instytucję ubezpieczeniową.
} 
macji w sposób komunikatywnie skuteczny (por. Albin 1998), właściwy terminologicznie i relewantny stylistycznie.

\section{Uwagi końcowe}

Wielość potencjalnych zadań stojących przed tłumaczem tekstów medycznych może adeptom tej sztuki wydać się nieco przytłaczająca, tłumacz tekstów medycznych w zakresie swoich działań zawodowych przekłada bowiem teksty zarówno do użytku wewnętrznego (np. w firmie farmaceutycznej), jak i do publikacji (w czasopismach naukowych), poprawia i dostosowuje teksty do zewnętrznych wymagań (w ramach korekty językowej), tłumaczy i uaktualnia strony internetowe (zawierające treści medyczne i pokrewne, np. dla szpitali i klinik w sektorze publicznym lub prywatnym), tłumaczy oprogramowanie lub instrukcje użytkowania (np. w przypadku wysoko technologicznie zaawansowanego nowoczesnego sprzętu medycznego czy też wyrobów medycznych), może też korygować i edytować teksty już przetłumaczone. Może też tworzyć terminologiczne bazy danych, planować czy zarządzać projektami tłumaczeniowymi bądź świadczyć usługi tłumaczeniowe jako tłumacz środowiskowy. Na tych wszystkich możliwych polach realizuje i weryfikuje swoje umiejętności i kwalifikacje, których ciągłe podnoszenie powinno być jego priorytetem. W tłumaczonych tekstach powinien natomiast zawsze zachować ostrożność w stosunku do źródeł, dokładne sprawdzić terminologię oraz przestrzegać jej spójności w tekście. Ważne jest również porównanie oryginału i tłumaczenia oraz dokładne sprawdzenie liczb i symboli, aby uniknąć popełnienia błędów typograficznych (np. przy zapisie w dawkowaniu leków), które mogą być powodem bardzo poważnych konsekwencji.

Niezbędne są zatem w tej pracy takie czynniki, jak: wiedza merytoryczna oraz motywacja do pogłębiania tej wiedzy, osobiste zaangażowanie, konsultacja $\mathrm{z}$ ekspertem/specjalistą z danej dziedziny, znajomość terminologii medycznej, dostęp do i umiejętność korzystania z informacji (słowniki, atlasy, podręczniki, glosariusze, leksykony, bazy danych on-line etc.), umiejętność tworzenia skutecznych komunikatywnie tekstów oraz doświadczenie i specjalizacja $\mathrm{w}$ połączeniu $\mathrm{z}$ chęcią rozwoju. Synergiczne działanie tych czynników z pewnością przyczyni się do generowania tłumaczeń wysokiej jakości. 


\section{Literatura}

Albin, V., 1998, "Translating and formatting medical texts for patients with low literacy skills", [w:] Translation and Medicine, H. Fischbach (red.), Amsterdam/Philadelphia, s. 117-129.

Amabile, T., 1996, Creativity in context, Westview.

Beeby, A., Ensinger, D., Presas, M., (red.), 2000, Investigating Translation Competence, Amsterdam.

Fischbach, H., 1998, Translation and Medicine, Amsterdam/Philadelphia.

Kościałkowska-Okońska, E., 2015, Tłumacz przysięgły a pułapki tekstów medycznych, „Rocznik Przekładoznawczy. Studia nad teorią, praktyką i dydaktyką przekładu”, M. Krajewska, L. Zieliński (red.), nr 10, s. 127-138.

Montalt-Resurrecció, V., Gonzalez Davies, M., 2007, Medical Translation Step by Step, Manchester.

Montalt-Resurrecció, V., Shuttleworth, M., 2012, Translation and knowledge mediation in medical and health settings. Linguistica Antverpiensia New Series - Themes in Translation Studies, Vol. 11, Antwerpia.

O’Neill, M., 1998, "Who Makes a Better Medical Translator: The Medically Knowledgeable Linguist or the Linguistically Knowledgeable Medical Professional? A Physician's Perspective”, [w:] Translation and Medicine, H. Fischbach (red.), Amsterdam/Philadelphia, s. 69-80.

Risku, H., 1998, Translatorische Kompetenz. Kognitive Grundlagen des Übersetzens als Expertentätigkeit, Tubingen.

Schäffner, C., Adab, B., (red.), 2000, Developing translation competence, Amsterdam.

On a career path: the translator of medical texts and profession-related requirements

Summary

Translation of medical texts embraces an entire range of various types of documents (e.g. official documentation related to commercialisation of medical products and devices, medical texts for educational and informational purposes or medical documentation of individuals). The language of medical texts - as a specialist variety of natural language - is very specific, and its ultimate objective is efficient communication and information transfer. The translator of medical texts is not only an expert on linguistic issues, but also a person who takes responsibility for the final product of the translation process that should be adequate and terminologically accurate. In 
this paper challenges and requirements - to be fulfilled by the translator of medical texts - shall be presented. These are not only the terminology in the sense of applying relevant medical terms and concepts but also cognitive factors and the willingness to learn, combined with practical manifestations of translation competence.

Keywords: medical translation, specialist language, medical text, terminology, competence 
